\title{
Emerging Pharmacological Properties of Cholinergic Synaptic Trans- mission: Comparison between Mammalian and Insect Synaptic and Extra- synaptic Nicotinic Receptors
}

\author{
Steeve H. Thany* and Hélène Tricoire-Leignel
}

Laboratoire Récepteurs et Canaux Ioniques Membranaires (RCIM), UPRES EA 2647/USC INRA 2023, Université d'Angers, UFR Sciences. 2 Bd Lavoisier, 49045 Angers cedex, France

\begin{abstract}
Acetylcholine (ACh) is probably the oldest signalling neurotransmitter which appeared in evolution before the nervous system. It is present in bacteria, algae, protozoa and plants. In insects and mammals it is involved in cell-to-cell communications in various neuronal and non-neuronal tissues. The discovery of nicotinic acetylcholine receptors (nAChRs) as the main receptors involved in rapid cholinergic neurotransmission has helped to understand the role of ACh at synaptic level. Recently, several lines of evidence have indicated that extrasynaptically expressed nAChRs display distinct pharmacological properties from the ones expressed at synaptic level. The role of both nAChRs at insect extrasynaptic and/or synaptic levels has been underestimated due to the lack of pharmacological tools to identify different nicotinic receptor subtypes. In the present review, we summarize recent electrophysiological and pharmacological studies on the extrasynaptic and synaptic differences between insect and mammalian nAChR subtypes and we discuss on the pharmacological impact of several drugs such as neonicotinoid insecticides targeting these receptors. In fact, nAChRs are involved in a wide range of pathophysiological processes such as epilepsy, pain and a wide range of neurodegenerative and psychiatric disorders. In addition, they are the target sites of neonicotinoid insecticides which are known to act as nicotinic agonists causing severe poisoning in insects and mammals.
\end{abstract}

Keywords: Nicotinic acetylcholine receptors, pharmacology, insect, mammal, synapse.

\section{INTRODUCTION}

Cholinergic synaptic transmission plays a key role in the nervous system and biochemical changes at the synapse underlie some aspects of the higher brain function. It is known that acetylcholine (ACh) activates both nicotinic and muscarinic receptors in the insect and mammalian central nervous system (CNS). The nicotinic acetylcholine receptors (nAChRs) of the mammals fall into at least two subfamilies, occurring on muscle fibres at the neuromuscular synapses and on neurons in the peripheral ganglia and in the brain. In mammals, previous studies indicate that neuronal nicotinic receptors can be either presynaptic or postsynaptic (Fig. 1) [1-4]. This assumption was confirmed by several studies showing that at the synaptic level, nicotinic receptors were associated with postsynaptic mediated excitation and membrane depolarization, while at presynaptic site, nAChRs activation could produce either excitation or inhibition indirectly through the release of endogenous transmitters or modulators. Consequently, they are likely to serve a number of physiological roles: they can act presynaptically to modulate neurotransmitter release and/or can function at extrasynaptic or synaptic sites to generate synaptic currents [5-10]. The availability of cDNA sequences coding for the neuronal nAChR subunits has made it possible to carry out studies on

\footnotetext{
*Address correspondence to this author at the Laboratoire Récepteurs et Canaux Ioniques Membranaires (RCIM), UPRES EA 2647/USC INRA 2023, Université d'Angers, UFR Sciences. 2 Bd Lavoisier, 49045 Angers cedex, France; Tel: +33 (0) 2417352 13; Fax: +33 (0) 2417352 15;

E-mail: steeve.thany@univ-angers.fr
}

the distribution, [11-15] subunit composition and pharmacological profile of vertebrate nAChR subtypes [16-22]. Subsequently, several agonists and antagonists have been found that are selective, to varying degrees, for particular subtypes of these receptors.

In insects, it has also been demonstrated that nAChRs mediate rapid synaptic neurotransmission, and some properties of the involved channels have been described [23-25]. Building on this conjecture, it was suggested that nAChRs in insects might retain features of the ligand-binding primordial to ACh-activated channels and that native nAChRs may manifest a homo- and hetero-oligomeric subunits structure as few nAChR subunits have been isolated [26-29]. Although sharing many pharmacological and physiological properties with mammalian neuronal nAChRs, insect nAChRs have marked differences in their insecticide sensitivity, synaptic distribution and functional properties. Besides the classical postsynaptic receptors for $\mathrm{ACh}$, nothing is known about the presynaptic nAChRs except that these receptors could mediate the release of ACh or modulate its release. This review will focus on the properties, mechanisms and pharmacological function of synaptic and extrasynaptic nicotinic receptors in insects. Our aim was to make a comparison of the cholinergic synaptic properties between insects and mammals.

\section{DIVERSITY OF INSECT AND MAMMALIAN NICOTINIC RECEPTOR SUBUNITS}

Knowledge of the molecular organization of vertebrate nAChRs from neuromuscular junction and neurons has led to $\alpha$ subunits $(\alpha 1$ to $\alpha 10)$ which have two vicinal cysteine 


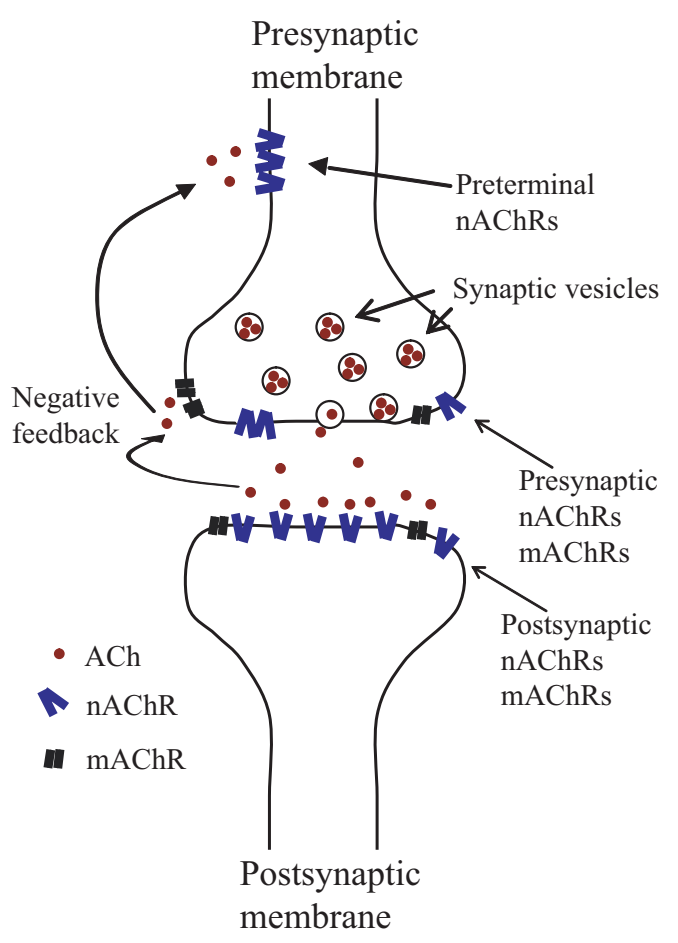

Fig. (1). Putative locations of neuronal nicotinic acetylcholine receptors. ACh released from presynaptic vesicules may diffuse and activate presynaptic nAChRs and mAChRs resulting in a modulation of neurotransmitter release (negative feedback).

residues equivalent to Torpedo Cys192 and Cys193 involved in ACh binding, and non- $\alpha$ subunits $(\beta, \gamma, \delta$ or $\varepsilon)$ which are lacking this motif. The vertebrate muscle $\mathrm{nAChR}$ is a functional multisubunit receptor with a generic stoichiometry of $2 \alpha 1, \beta, \gamma, \delta$ or $\varepsilon$. The $\gamma$ subunit is expressed embryonically and is replaced by $\varepsilon$ subunit at synaptic junction in adult muscle [30]. Neuronal nAChRs constitute a more diverse family of receptors forming homo- and hetero-oligomeric channels $[17,19,31-34]$. The vertebrate nomenclature system is based on the subunits that compose those receptor types to the extent that information such as amino acid or nucleic acid sequences are available (e.g., the $\alpha 2$ subunit gene encodes the $\alpha 2$ subunit). Then, vertebrates possess at least 16 subunits while insects have more than 10 subunits $[28,35,36]$ but their diversity is increased by RNA editing $[27,37,38]$.

Comparison between rat and human amino acid sequences typically reveals over $80 \%$ identity for a given nAChR subunit, allowing us to consider that Rattus norvegicus $\alpha 2$ subunit is similar to the Homo sapiens $\alpha 2$ one and in general to all vertebrate $\alpha 2$ subunits than Rattus norvegicus $\alpha 7$ subunit. The nomenclature currently used in insect is based on sequence apparition order which is reasonably insensible to subunit sequence homology between insect. For example the first peach potato aphid subunit discovered and named $\alpha 1$ is widely more homologous to the drosophila $\alpha 2$ subunit than the second identified peach potato aphid subunit named $\alpha 2$, which is homologous to the drosophila $\alpha 1$ one [28, 39]. Moreover in some cases, several nomenclatures exist for the same sequence subunit as in the drosophila: then, the drosophila second beta subunit [40] could be referred to as SBD, $\mathrm{D} \beta 2$ and $\mathrm{nAcR} \beta-96 \mathrm{~A}$, this last nomenclature taking into account the gene's chromosomal location as proposed by FlyBase (http://flybase.bio.indiana. edu). This does not provide a mechanism by which the nomenclature of genes and sequences from different insect species can be rationalised. Nevertheless, it was proposed that insect nAChRs, like mammalian neuronal nAChRs, are composed of five subunits, and can be pharmacologically subdivided into alpha-bungarotoxin $(\alpha-B g t)$-sensitive and insensitive receptors [28] with the assumption that vertebrate $\alpha$-Bgt-sensitive receptors form functional homo-oligomeric channels.

\section{INSECT POSTSYNAPTIC NICOTINIC RECEPTORS}

Studies on the pharmacology of cholinergic synaptic transmission in insects have largely centred on the connections between afferents sensory neurons with interneurons or with motoneurons in several insects such as the cockroach Periplaneta americana, [41-45] and the tobacco hornworm, Manduca sexta [46]. It has been demonstrated that the postsynaptic neurons possess receptors which have an essentially nicotinic pharmacology: the most prominent effect of ACh is mediated by nicotinic receptors which generate fast excitatory postsynaptic potentials $[47,48]$ Several data have been obtained from cholinergic synaptic transmission at the cercal afferent-giant interneuron synapse in the cockroach sixth abdominal ganglion. Individual giant interneurons can be identified by their unique morphological characteristics and localization [42, 43, 49-51]. Iontophoretic injection of ACh onto the finer branches of giant interneurons resulted in a dose-dependent depolarization of a giant interneuron accompanied by a decrease in membrane resistance $[43,50,51]$. Following this experiment, profiles of ACh sensitivity were correlated with the distribution of the finer postsynaptic branches of a giant interneuron [52] as ACh-induced postsynaptic potentials were blocked by $\alpha$-Bgt and also as the decline in amplitude of excitatory postsynaptic potentials (EPSPs) was associated with the response of giant interneuron to ACh [53, 54]. It was interesting to note that the minimal quantity of ACh required to generate a depolarizing response of giant interneuron (GI) 1 was estimated to $3.0 \times 10^{-17} \mathrm{~mol}$ [51] which was comparable to values determined for vertebrates cholinergic synaptic transmission, close to $2.0 \times 10^{-18}$ mol [55,56]. A similar action of ACh through activation of postsynaptic nAChRs could be also identified at the monosynaptic connections between the trochanteral hairplate afferents and motoneuron $D_{s}$ of the metathoracic ganglion $[57,58]$, and in embryonic drosophila neurons in vitro [59].

\section{PRESYNAPTIC ACETYLCHOLINE RECEPTORS: MUSCARINIC OR NICOTINIC RECEPTORS ?}

In the conventional synapse, $\mathrm{ACh}$ released from the presynaptic vesicles, targets the postsynaptic nAChRs and opens ion gates. On the other hand, receptor sites were far from the release site. Terms of presynaptic receptors were defined as receptors at or near the nerve terminal (Fig. 1) which can positively or negatively modulate transmitter release $[8-10,60]$. In several studies, the sodium channel blocker, tetrodotoxin (TTX) has been used to define presynaptic nAChRs because in the presence of this toxin, action potentials arriving at the presynaptic terminals were elimi- 
nated $[5,61]$. In the chick midbrain, accessory motoneurons extend their axons to the ciliary ganglion where they terminate in large calyces on ciliary cells [61-63]. Bath application of nicotine induced inward currents in the calyces capable of generating action potentials (APs). At presynaptic site, it was found that TTX blocked the APs but not the inward currents while $\alpha$-Bgt blocked both. At postsynaptic level, $\alpha$ Bgt was a partial antagonist and d-tubocurarine a full antagonist on nicotine-induced currents [61]. These results were consistent with the presynaptic action of nicotine through $\alpha$-Bgt-sensitive $\alpha 7 \mathrm{nAChR}$ subtype. Similar activation of presynaptic $\alpha 7$ and non- $\alpha 7 \mathrm{nAChRs}$ has been identified in the rat sub-cortical regions, the frontal cortex and other vertebrate tissues $[7,10,60]$.

The limited examples of excitatory or inhibitory ACh transmission through insect presynaptic nAChRs have prompted the hypothesis that the receptors serve other functions. Thus, intracellular microelectrode recording and ionophoretic application of carbamylcholine $(\mathrm{CCh})$ were used to compare the cholinergic sensitivity of postsynaptic dendrites of giant interneuron 3 (GI 3) with that of presynaptic cholinergic axon of the lateral filiform hair sensory neuron (LFHSN) in the first-instar cockroach Periplaneta americana [64]. CCh responses of GI 3 and LFHSN were blocked by mecamylamine and d-tubocurarine but were not affected by muscarinic antagonists. From their studies, Blagburn and Sattelle [64] suggested that presynaptic nAChRs could be present in the axon membrane. They propose three possible locations of the ACh receptors on LFHSN: (1) postsynaptic to cholinergic input synapses onto the axon, (2) presynaptic to cholinergic output synapses made by the axon and (3) extrasynaptic [64]. Unfortunately, no clear evidence of insect presynaptic nAChRs has been demonstrated, and it was currently admitted that the postsynaptic neurons possess receptors that have an essentially nicotinic pharmacology mediating fast excitatory postsynaptic potentials (EPSPs) and that presynaptic receptors have only a muscarinic profile $[46,65,66]$. Evidence involving muscarinic receptors in synaptic function was obtained with the locust, Locusta migratoria, synaptosome preparation. It was found that these muscarinic receptors were similar to the mammalian $\mathrm{M}_{2}$ subtype receptor [67]. Electrophysiological studies performed on cockroach cercal nerve-giant fiber preparation have identified two distinct muscarinic receptor subtypes. The first subtype was present on the cercal afferent terminal with a pharmacological profile similar to the vertebrate M2 receptor, and the second muscarinic receptor was found on the membrane of the postsynaptic giant interneurons [65,68-70]. It was suggested that the presynaptic muscarinic receptors acted as autoreceptors regulating the release of ACh [65, 66, 68] while postsynaptic muscarinic receptors reduced the giant fiber spike threshold [71]. Comparable studies have been performed in other insects such as the locust Schistocerca gregaria [66] and the tobacco hornworm, Manduca sexta $[46,72]$. The monosynaptic connection between sensory neurons and identified proleg motoneuron of the tobacco hornworm, Manduca sexta presents common characteristics with the cockroach cercal nerve-giant fiber. In fact, sensory neurons associated with a planta hair send an axon into the ganglion of the same segment where the afferent terminals make synaptic contact with interneurons and motoneurons such as proleg motoneuron (called PPR) [46, 72]. Trains of afferent activity cause a slow, long lasting depolarization that modulates PPR's excitability. These EPSPs are mediated by mAChRs because they can be blocked by muscarinic antagonists and mimicked by agonists [46]. Thus, the responsiveness of motoneurons can be controlled by ACh through mAChRs [72].

\section{NICOTINIC RECEPTORS EXPRESSED ON ISO- LATED CELL BODIES}

In the vertebrates, the availability of stable host cells expressing $\mathrm{nAChR}$ subtypes from humans or rats allowed further examination of nAChR pharmacology [73]. In fact, responses from native $\alpha 7 \mathrm{nAChR}$ demonstrate that the $\alpha 7$ subunit, when heterologously expressed in Xenopus oocytes, assembles into homopentameric ligand-gated ion channels that are cation-selective, rapidly desensitize and bind $\alpha-B g t$ with high affinity $[74,75]$. Thus, there was a strong correlation between native and expressed nAChR subtypes. Consequently, the minimum subunit combinations capable of forming functional receptors on expression systems have constrained views of the subunit composition of native neuronal nAChRs. Evidence obtained in host cells confirmed that pairwise combination of $\alpha 2, \alpha 3$ or $\alpha 4$ with $\beta 2$ or $\beta 4$ subunit generates heteromeric functional receptors $[18,76$, 77] while $\alpha 7$ and $\alpha 9$ make an homomeric receptor $[17,74,75]$. One exception was that $\alpha 10$ subunit alone yielded no detectable functional receptors. However, coinjection with $\alpha 9$ subunit results in a functional nAChR subtype $[17,19,78]$. Consequently, two pharmacologically distinct nAChR subfamilies could be classified in the vertebrate: the $\alpha$-Bgt-sensitive receptors which include the lowaffinity homo-oligomer $\alpha 7$ receptor and the $\alpha$-Bgtinsensitive receptors, which include the high-affinity heterooligomeric $\alpha 4 \beta 2$ receptor, widely distributed in the brain.

The only expression of insect nAChR subunit in Xenopus oocytes was achieved with the locust, Schistocerca gregaria, $\alpha$-like subunit $\alpha \mathrm{L} 1[79,80]$. Compared to chick $\alpha 7$ responses, $\alpha \mathrm{L} 1$ subunits were also able to form a homooligomeric channel which was blocked by $\alpha$-Bgt and methyllicaconitine (MLA) but differed from $\alpha 7$ receptors in nicotine sensitivity and timecourse of evoked currents [80]. $\alpha \mathrm{L} 1$ receptor is markedly less sensitive to nicotine than $\alpha 7$ receptor and current-voltage relationship was shifted towards more positive potentials, compared with $\alpha 7$ currents [80]. These results demonstrated that when experimental verification was possible, insect homomeric nAChRs could be pharmacologically distinct from vertebrate homomeric receptors. The last expression of insect nAChR subunit in heterologous systems was recently achieved by the cloning, sequencing and functional expression of a novel locust (Schistocerca gregaria) $\beta$ subunit [81]. When co-expressed with a $\alpha \mathrm{L} 1$ subunit, the pharmacology of the heteromeric receptor was indistinguishable from the one of the receptor based on a $\alpha \mathrm{L} 1$ subunit alone [81]. On the other hand, oocytes co-injected with $\alpha \mathrm{L} 1$ and $\operatorname{Sg} \beta 1$ responded to nicotine with membrane depolarizations, although the peak depolarization amplitude did not differ from those responses with 
$\alpha \mathrm{L} 1$ homomeric receptors. Because the pharmacological profile of the $\alpha \mathrm{L} 1 / \operatorname{Sg} \beta 1$ heteromeric receptor refers to the $\alpha \mathrm{L} 1$ homomeric receptor, Jones et al. [81] suggested that the $\mathrm{Sg} \beta 1$ subunit was not able to form functional $\mathrm{nAChR}$ when co-expressed with $\alpha \mathrm{L} 1$. This point was restrained by the finding that the vertebrate and insect $\beta$ subunits are apparently incapable of forming functional $\mathrm{nAChR}$ alone. The most plausible explanation was given from vertebrate nAChRs obtained in transfected cell lines expressing either the human or rat nAChRs. It was observed that upregulation mechanisms differ from one expression system to another [82-86]. These mechanisms could alter functional expression of insect nAChRs in host cells. A second explanation could be that more complex subunit combinations are necessary because evidence for insect neuronal $\mathrm{nAChR}$ comprised of three subunits is accruing [87, 88]. In all cases, contrary to vertebrate nAChRs, the pharmacological profile of insect nAChRs associated with subunit composition was difficult to perform through host cells.

The initial experiments on native insect neurons were performed on the somata of neurons isolated on dorsal unpaired median (DUM) neurons of the grasshopper, Schistocerca nitens $[89,90]$. It has been shown that ACh-induced depolarizations were blocked by d-tubocurarine while $\alpha$-Bgt failed to block the currents [90], suggesting a lack of $\alpha$-Bgtsensitive nAChRs. In line with this study, Lane et al. [91] demonstrated that $\alpha$-Bgt blocked the depolarizing response to ionophoretic application of ACh onto the cell body membrane of the cockroach fast coxal depressor $\left(\mathrm{D}_{\mathrm{f}}\right)$ motoneuron but was completely ineffective in blocking the depolarizing action on DUM neurons [91]. These first results suggested a difference between nAChRs expressed on both DUM neurons and motoneuron $\mathrm{D}_{\mathrm{f}}$ and likely that more than one type of nicotinic acetylcholine receptors was expressed in the isolated cells. Substantial investigation performed on cockroach neurons revealed the existence of $\alpha$-Bgt-sensitive and -insentive nAChRs expressed on DUM neurons [92-94] and on neurons isolated from thoracic ganglia, two distinct $\alpha$ Bgt-sensitive nAChR subtypes with distinct kinetic and pharmacological properties: a desensitized and a nondesensitized receptor named $\mathrm{nAChD} n \mathrm{nChRN}$, respectively [95].

\section{INSECT NICOTINIC ACETYLCHOLINE RECEP- TORS AND NON-CHOLINERGIC NEURONS}

In non-cholinergic neurons such as dopaminergic, GABAergic and glutamatergic neurons, several vertebrate pre-synaptic nAChRs have been identified with a modulatory role on neurotransmission [96-100]. For example $\alpha 7$ nAChR subtype was involved in nicotine-mediated glutamate release and non- $\alpha 7$ subtype was involved in nicotinemediated GABA release [96]. In addition, nAChR located on GABAergic interneurons reduced the GABA-mediated inhibition of dopamine (DA) release, thereby indirectly eliciting DA release [97, 98]. Moreover, it has been proposed that striatal muscarinic receptors (mAChRs) such as M2 and M4 receptors, by inhibiting $\mathrm{ACh}$ release from cholinergic interneurons, modify nAChR activity controlling DA release from dopaminergic neurons, suggesting that in other regions such as striatum and nucleus accumbens, there is evidence for presynaptic muscarinic receptors [101]. In all cases, pre- sysnaptic muscarinic and nicotinic receptors have been identified in the vertebrate non-cholinergic neurons and their function was to modulate and/or inhibit neurotransmitter release.

Despite that vertebrate nAChR subunits have been found on the soma of DA neurons [102] as well as on GABAergic terminals $[103,105]$, there was no clear evidence of specific nAChR subunit on insect non-cholinergic neurons. Physiological recordings in drosophila, locust and honeybee indicated that Kenyon cells (KCs) receive olfactory associative information directly from cholinergic projection neurons (PNs) located in the antennal lobes (ALs) and indirectly via GABAergic lateral horn neurons [106-109]. Excitatory information arrives from PNs located in the ALs while GABAergic lateral horn neurons, activated by odors, provided inhibitory inputs to the Kenyon cells (Fig. 2A) $[110,111]$. Note that, within the lip region of the honeybee Apis mellifera, PNs make synapses onto GABAergic neurons which in turn send inhibitory synapses within PNs and $\mathrm{KCs}$ while GABAergic feedback neurons receive input in the mushroom bodies (MBs) and send their axons to the calyx lip region [110-112]. Further investigations in the drosophila demonstrated that $\mathrm{KCs}$ expressed $\alpha$-Bgt-sensitive nAChRs which mediate fast excitatory synaptic transmission [113, 114]. Moreover, drosophila neuronal cultures in which cholinergic and GABAergic synapses are functionally formed revealed that DA suppressed cholinergic synaptic currents [115]. In fact, application of ACh and GABA on cultured KCs reveal that they express both nAChRs and GABA receptors [116-118]. These studies demonstrated that both $\mathrm{nAChRs}$ and GABA receptors were expressed in the same neurons.

\section{TOXICOLOGICAL MECHANISMS OF NEONI- COTINOID ACTIONS ON INSECT AND MAMMAL- IAN nAChRs}

Neonicotinoid insecticides represent a relatively new group of chemicals that includes imidacloprid, thiamethoxam, clothianidin and acetamiprid. They are highly efficient in suppressing the overwhelming majority of crop pests. It was known that the insecticidal activity of neonicotinoids is due to their agonist action on nicotinic receptors. At synaptic level, nenonicotinoid insecticides probably affect postsynaptic nAChRs $[119,120]$ less than presynaptic receptors. In fact, bath application of clothianidin on giant interneuron synapses induced a strong depolarization which was not blocked by muscarinic antagonists suggesting that its effect occurred on postsynaptic nicotinic receptors [120]. This synaptic effect could account for neonicotinoid symptoms described in the cockroach [121]. In fact, Tan et al. [121] have distinguished two neonicotinoid insecticide subgroups according to their effects. The first subgroup includes molecules resulting in strong excitation symptoms with uncoordinated quivering, hyper-excitability and rapid spontaneous movements of cockroaches, while there was no excitation symptoms in the second subgroup [121]. Although several electrophysiological studies have shown that neonicotinoid insecticides are likely to be low toxic in humans [122-124], several cases of acute poisoning have been associated with the development and the use of these insecticides [125, 126]. They share a similar mechanism of toxicity and therefore 
presenting patients have comparable symptoms such as respiratory, gastrointestinal, cardiovascular and central nervous system effects [126]. This apparent neonicotinoid toxicity, if associated with direct effect, suggests that the low affinity of these ligands to mammalians nAChRs must be clarified. In fact, we have recently found that thiamethoxam which was a poor agonist of insect nAChR on isolated cell bodies was able to generate a strong depolarization of the $6^{\text {th }}$ abdominal ganglion (personal observation). This effect suggested that there was a distinct effect of thiamethoxam on nAChRs expressed on isolated cell bodies compared to the one expressed at synaptic level.

\section{CONCLUSIONS AND FUTURE PROSPECTS}

The results of our initial efforts to compare insect and mammalian $\mathrm{nAChR}$ function suggested that according to pharmacological properties there is a strong correlation between insect and vertebrate nAChRs through their sensitivity to the weak agonist nicotine and the antagonist $\alpha$-Bgt. In terms of antagonists, insect as well as vertebrate nAChRs were differentiated into two distinct nAChR subtypes: $\alpha$ Bgt-sensitive and -insensitive receptors. However, there were two striking differences. The first was that expressed insect neuronal $\mathrm{nAChRs}$ of matching subunit composition can differ markedly from the vertebrate nAChRs in showing lower or higher sensitivity. The second was that presynaptic localization of insect nAChRs remains to be demonstrated (See Fig. 2B), which is not the case for vertebrate nAChRs.

The existence of multiple classes of insect $\mathrm{nAChR}$ found on isolated cell bodies does not preclude the existence of these receptors at synaptic level. As shown above, vertebrate nicotinic receptors sensitive to $\alpha$-Bgt are present at presynaptic and postsynaptic levels. Although it was demonstrated that insect and vertebrate isolated cell bodies present $\alpha$-Bgtsensitive and -insensitive nAChRs, the former was not clear at insect presynaptic site. This lack of formal studies allows us to consider that only muscarinic receptors were expressed at insect presynaptic site and consequently account for the modulation of ACh release. In fact, works on cockroach and locust have provided evidence for postsynaptic function of nicotinic receptors and a presynaptic function of muscarinic receptors. It was noted that these postsynaptic nAChRs can be modulated by both muscarinic cholinergic and serotoninergic pathways $[127,128]$. In this case, muscarinic pathway may act as a feedback mechanism to control ACh excitability to prevent excessive repeated depolarization but also regulate the actions of the inhibitory neurotransmitter GABA. Considering studies from vertebrate nAChRs showing the involvement of these receptors on presynaptic level and that in all the insects species investigated, a much higher density of CNS nicotinic receptors is detected compared to muscarinic receptors; therefore it would be conceivable to suggest that insect nAChRs could account for the same complex processes at presynaptic site.

In conclusion, insects provide material suited to developmental and genetic approaches to the study of nicotinic receptors, their involvement in learning and memory processes and the toxic effect of active compounds such as
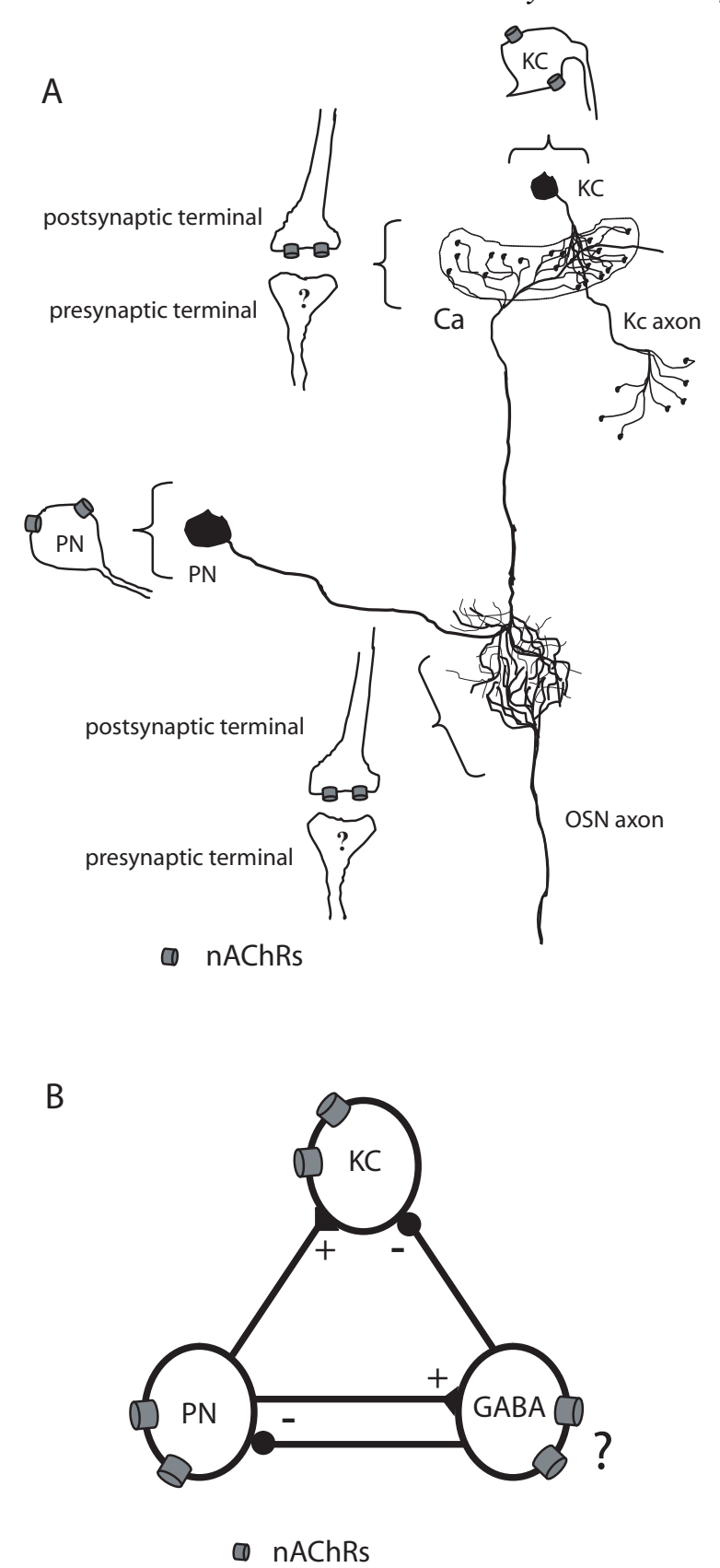

Fig. (2). Putative locations of insect nicotinic receptors. (A) Olfactory sensory neurons (OSN) extend dorsally toward the brain and synapse in the glomerulus in the antennal lobe (AL). The cell body of projection neuron (PN) synapses with OSN in the antennal lobes and extend its axon dorsally to make synapses in the mushroom body calyx (Ca). Kenyon cells (KCs) axons target output neurons in the vertical and medial lobes of the mushroom bodies (also called $\alpha$ and $\beta$ lobes). Following electrophysiological studies, nicotinic receptors could be localized on the cell bodies of $\mathrm{KC}$, at postsynaptic sites between OSN and PN and also between PN and KC. (B) Synaptic connections between antennal lobe projection neurons $(\mathrm{PN})$, Kenyon cells (KCs) and GABAergic inhibitory neurons within the mushroom body calyx neuropil. (?) indicates the putative locations of nicotinic receptors.

neonicotinoid insecticides. This will help in providing new approaches to the chemical control of insect pests of agricul- 
tural, veterinary and medical importance. The development of novel nicotinic ligands for the treatment of cognitive deficits or as neonicotinoid insecticides depends on determining the differential roles of various nicotinic receptor subtypes. Key questions for future research: (1) Does insect presynaptic cholinergic neurons express nAChRs and if so, which subtypes? (2) What is the in vivo relevance of $\mathrm{nAChRs}$ expressed on isolated cell bodies while they did not receive efferent inputs? In fact, nAChRs have also been identified on the cell bodies of several insects [28] such as honeybee KCs and ALs [117, 118, 131, 132].

\section{ACKNOWLEDGEMENTS}

Authors would like to thanks Dr. Alain Hamon, Hervé Le Corronc and Prof. Monique Gauthier for their help during the manuscript process.

\section{REFERENCES}

[1] Brown, D. A.; Docherty, R. J.; Halliwell, J. V. The action of cholinomimetic substances on impulse conduction in the habenulointerpeduncular pathway of the rat in vitro. J. Physiol., 1984, 353, 101119.

[2] Clarke, P. B.; Pert, A. Autoradiographic evidence for nicotine receptors on nigrostriatal and mesolimbic dopaminergic neurons. Brain Res., 1985, 348, 355-358.

[3] Hamill, G. S.; Clarke, P. B.; Pert, A.; Jacobowitz, D. M. 3Hnicotine and 125I-alpha-bungarotoxin-labeled nicotinic receptors in the interpeduncular nucleus of rats. I. Subnuclear distribution. $J$. Comp. Neurol., 1986, 251, 398-406.

[4] Clarke, P. B.; Hamill, G. S.; Nadi, N. S.; Jacobowitz, D. M.; Pert, A. 3H-nicotine- and 125I-alpha-bungarotoxin-labeled nicotinic receptors in the interpeduncular nucleus of rats. II. Effects of habenular deafferentation. J. Comp. Neurol., 1986, 251, 407-413.

[5] McGehee, D. S.; Heath, M. J.; Gelber, S.; Devay, P.; Role, L. W. Nicotine enhancement of fast excitatory synaptic transmission in CNS by presynaptic receptors. Science, 1995, 269, 1692-1696.

[6] Gray, R.; Rajan, A. S.; Radcliffe, K. A.; Yakehiro, M.; Dani, J. A. Hippocampal synaptic transmission enhanced by low concentrations of nicotine. Nature, 1996, 383, 713-716.

[7] Rousseau, S. J.; Jones, I. W.; Pullar, I. A.; Wonnacott, S. Presynaptic alpha7 and non-alpha7 nicotinic acetylcholine receptors modulate $[3 \mathrm{H}] \mathrm{d}$-aspartate release from rat frontal cortex in vitro. Neuropharmacology, 2005, 49, 59-72.

[8] Wonnacott, S. Presynaptic nicotinic ACh receptors. Trends Neurosci., 1997, 20, 92-98.

[9] Vizi, E. S.; Lendvai, B. Modulatory role of presynaptic nicotinic receptors in synaptic and non-synaptic chemical communication in the central nervous system. Brain Res. Brain Res. Rev., 1999, 30, 219-235.

[10] Lendvai, B.; Vizi, E. S. Nonsynaptic chemical transmission through nicotinic acetylcholine receptors. Physiol. Rev., 2008, 88, 333-349.

[11] Daubas, P.; Salmon, A. M.; Zoli, M.; Geoffroy, B.; DevillersThiery, A.; Bessis, A.; Medevielle, F.; Changeux, J. P. Chicken neuronal acetylcholine receptor alpha 2-subunit gene exhibits neuron-specific expression in the brain and spinal cord of transgenic mice. Proc. Natl. Acad. Sci. USA, 1993, 90, 2237-2241.

[12] Simmons, D. D.; Morley, B. J. Differential expression of the alpha 9 nicotinic acetylcholine receptor subunit in neonatal and adult cochlear hair cells. Brain Res. Mol. Brain Res., 1998, 56, 287-292.

[13] Arroyo-Jim nez, M. M.; Bourgeois, J. P.; Marubio, L. M.; Le Sourd, A. M.; Ottersen, O. P.; Rinvik, E.; Fairen, A.; Changeux, J. P. Ultrastructural localization of the alpha4-subunit of the neuronal acetylcholine nicotinic receptor in the rat substantia nigra. J. Neurosci., 1999, 19, 6475-6487.

[14] Bitner, R. S.; Nikkel, A. L. Alpha-7 nicotinic receptor expression by two distinct cell types in the dorsal raphe nucleus and locus coeruleus of rat. Brain Res., 2002, 938, 45-54.

[15] Tribollet, E.; Bertrand, D.; Marguerat, A.; Raggenbass, M. Comparative distribution of nicotinic receptor subtypes during devel- opment, adulthood and aging: an autoradiographic study in the rat brain. Neuroscience, 2004, 124, 405-420.

[16] Heinemann, S.; Boulter, J.; Deneris, E.; Connolly, J.; Gardner, P.; Wada, E.; Wada, K.; Duvoisin, R.; Ballivet, M.; Swanson, L.; Patrick, J. Brain and muscle nicotinic acetylcholine receptors : a gene family In Molecular biology of neuroreceptors and ion channels, Maelicke, A., Ed. Springer-Verlag: Berlin Heidelberg, 1989; Vol. H32, pp 13-30.

[17] Elgoyhen, A. B.; Johnson, D. S.; Boulter, J.; Vetter, D. E.; Heinemann, S. Alpha 9: an acetylcholine receptor with novel pharmacological properties expressed in rat cochlear hair cells. Cell, 1994, 79, 705-715.

[18] Buisson, B.; Vallejo, Y. F.; Green, W. N.; Bertrand, D. The unusual nature of epibatidine responses at the alpha4beta2 nicotinic acetylcholine receptor. Neuropharmacology, 2000, 39, 2561-2569.

[19] Elgoyhen, A. B.; Vetter, D. E.; Katz, E.; Rothlin, C. V.; Heinemann, S. F.; Boulter, J. alpha10: a determinant of nicotinic cholinergic receptor function in mammalian vestibular and cochlear mechanosensory hair cells. Proc. Natl. Acad. Sci. USA, 2001, 98, 3501-3506.

[20] Buisson, B.; Bertrand, D. Chronic exposure to nicotine upregulates the human (alpha)4((beta)2 nicotinic acetylcholine receptor function. J. Neurosci., 2001, 21, 1819-1829.

[21] Virginio, C.; Giacometti, A.; Aldegheri, L.; Rimland, J. M.; Terstappen, G. C. Pharmacological properties of rat alpha 7 nicotinic receptors expressed in native and recombinant cell systems. Eur. J. Pharmacol., 2002, 445, 153-161.

[22] Papke, R. L.; Dwoskin, L. P.; Crooks, P. A. The pharmacological activity of nicotine and nornicotine on nAChRs subtypes: relevance to nicotine dependence and drug discovery. J. Neurochem., 2007, 101, 160-167.

[23] Suter, C.; Usherwood, P. N. Action of acetylcholine and antagonists on somata isolated from locust central neurons. Comp. Biochem. Physiol. C, 1985, 80, 221-229.

[24] Breer, H.; Sattelle, D. B. Molecular properties and functions of insect acetylcholine receptors. J. Insect Physiol., 1987, 33, 771790.

[25] Beadle, D. J.; Horseman, G.; Pichon, Y.; Amar, M.; Shimahara, T. Acetylcholine-activated ion channels in embryonic cockroach neurones growing in culture. J. Exp. Biol., 1989, 142, 337-355.

[26] Sattelle, D. B.; Jones, A. K.; Sattelle, B. M.; Matsuda, K.; Reenan, R.; Biggin, P. C. Edit, cut and paste in the nicotinic acetylcholine receptor gene family of Drosophila melanogaster. Bioessays, 2005, 27, 366-76

[27] Jones, A. K.; Grauso, M.; Sattelle, D. B. The nicotinic acetylcholine receptor gene family of the malaria mosquito, Anopheles gambiae. Genomics, 2005, 85, 176-187.

[28] Thany, S. H.; Lenaers, G.; Raymond-Delpech, V.; Sattelle, D. B.; Lapied, B. Exploring the pharmacological properties of insect nicotinic acetylcholine receptors. Trends Pharmacol. Sci., 2007, 28, 1422.

[29] Jones, A. K.; Sattelle, D. B. The cys-loop ligand-gated ion channel gene superfamily of the red flour beetle, Tribolium castaneum. BMC Genom., 2007, 8, 327.

[30] Witzemann, V.; Barg, B.; Nishikawa, Y.; Sakmann, B.; Numa, S., Differential regulation of muscle acetylcholine receptor gammaand epsilon-subunit mRNAs. FEBS Lett., 1987, 223, 104-112.

[31] Changeux, J. P.; Benoit, P.; Bessis, A.; Cartaud, J.; DevillersThiery, A.; Fontaine, B.; Galzi, J. L.; Klarsfeld, A.; Laufer, R.; Mulle, C.; et al. The acetylcholine receptor: functional architecture and regulation. Adv. Second Messenger Phosphoprotein Res., 1990, 24, 15-19.

[32] Changeux, J. P. The TiPS lecture. The nicotinic acetylcholine receptor: an allosteric protein prototype of ligand-gated ion channels. Trends Pharmacol. Sci., 1990, 11, 485-492.

[33] Le Novere, N.; Changeux, J. P. The ligand gated ion channel database. Nucleic Acids Res., 1999, 27, 340-342.

[34] Le Novere, N.; Changeux, J. P. LGICdb: the ligand-gated ion channel database. Nucleic Acids Res., 2001, 29, 294-295.

[35] Dent, J. A. Evidence for a diverse Cys-loop ligand-gated ion channel superfamily in early bilateria. J. Mol. Evol., 2006, 62, 523-535.

[36] Sine, S. M.; Wang, H. L.; Hansen, S.; Taylor, P. On the origin of ion selectivity in the Cys-loop receptor family. J. Mol. Neurosci., 2010, 40, 70-76. 
[37] Grauso, M.; Reenan, R. A.; Culetto, E.; Sattelle, D. B. Novel putative nicotinic acetylcholine receptor subunit genes, Dalpha5, Dalpha6 and Dalpha7, in Drosophila melanogaster identify a new and highly conserved target of adenosine deaminase acting on RNA-mediated A-to-I pre-mRNA editing. Genetics, 2002, 160, 1519-1533.

[38] Jones, A. K.; Sattelle, D. B. Diversity of insect nicotinic acetylcholine receptor subunits. In Insect nicotinic acetylcholine receptors, Thany, S. H., Ed. Landes Bioscience / Springer: Austin, Texas (USA), 2010; Vol. 683, pp 25-43.

[39] Sgard, F.; Fraser, S. P.; Katkowska, M. J.; Djamgoz, M. B.; Dunbar, S. J.; Windass, J. D. Cloning and functional characterisation of two novel nicotinic acetylcholine receptor alpha subunits from the insect pest Myzus persicae. J. Neurochem., 1998, 71, 903-912.

[40] Sawruk, E.; Udri, C.; Betz, H.; Schmitt, B., SBD, a novel structural subunit of the Drosophila nicotinic acetylcholine receptor, shares its genomic localization with two alpha-subunits. FEBS Lett., 1990, $273,177-181$.

[41] Callec, J. J.; Boistel, J. [Study of different types of electric activity recorded by capillary microelectrodes at the level of the lower abdominal ganglion in the cockroach, Periplaneta americana L.]. $C$. R. Seances Soc. Biol. Fil., 1966, 160, 1943-1947.

[42] Callec, J. J.; Guillet, J. C.; Pichon, Y.; Boistel, J., [Relations between the activity of cercal mechanoreceptors and the corresponding postsynaptic potentials gathered at the level of an isolated giant fiber of the cockroach (Periplaneta americana)]. J. Physiol. (Paris), 1969, 61, 98.

[43] Callec, J. J. Synaptic transmission in the central nervous system of insects. J.E. Treherne. North-holland, American Elsevier Ed.; 1974; Vol. 35, p 119-185.

[44] Sattelle, D. B.; Harrow, I. D.; Hue, B.; Pelhate, M.; Gepner, J. I.; Hall, L. M. $\alpha$-bungarotoxin blocks excitatory synaptic transmission between cercal sensory neurones and giant interneurone 2 of the cockroach. Periplaneta americana. J. Exp. Biol., 1983, 107, 473489 .

[45] Pitman, R. M. Comprehensive insect physiology pharmacology In Nervous system, Pergamon ed.; Kerkut, Gilbert, L.I., G. Eds. Pergamon Press: Oxford, 1985; Vol. 11, pp 5-54.

[46] Trimmer, B. A.; Weeks, J. C. Effects of nicotinic and muscarinic agents on an identified motoneurone and its direct afferent inputs in larval Manduca sexta. J. Exp. Biol., 1989, 144, 303-337.

[47] Weeks, J. C.; Jacobs, G. A. A reflex behavior mediated by monosynaptic connections between hair afferents and motoneurons in the larval tobacco hornworm, Manduca sexta. J. Comp. Physiol. A, 1987, 160, 315-329.

[48] Sattelle, D. B.; Breert, H. Cholinergic nerve terminals in the central nervous system of insects. J. Neuroendocrinol., 1990, 2, 241-256.

[49] Callec, J. J.; Guillet, J. C.; Pichon, Y.; Boistel, J. Further studies on synaptic transmission in insects. II. Relations between sensory information and its synaptic integration at the level of a single giant axon in the cockroach. J. Exp. Biol., 1971, 55, 123-149.

[50] Callec, J. J.; Sattelle, D. B. A simple technique for monitoring the synaptic actions of pharmacological agents. J. Exp. Biol., 1973, 59, 725-738.

[51] Callec, J. J.; david, J. A.; Sattelle, D. B. Ionophoretic application of acetylcholine on to the dendrites of an identified giant interneurone (GI 1) in the cockroach Periplaneta americana. J. Insect. Physiol., 1982, 28, 1003-1008.

[52] Harrow, I. D.; Hue, B.; Pelhate, M.; Sattelle, D. B. Cockroach giant interneurones stained by cobalt-backfilling of dissected axons. $J$. Exp. Biol., 1980, 84, 341-343.

[53] Harrow, I. D.; Hue, B.; Gepner, J. I.; Hall, L. M.; Sattelle, D. B. An alpha-bungarotoxin sensitive acetylcholine receptor in the central nervous system of the cockroach, Periplaneta americana. In Neurotox 79, Sherwood, M., Ed. Plenum Press: New York, 1980; pp 137-144.

[54] Harrow, I. D.; Hue, B.; Pelhate, M.; Sattelle, D. B. Alphabungarotoxin blocks excitatory post-synaptic potentials in an identified insect interneurones. J. Physiol. (London), 1979, 295, 63-64.

[55] Harris, A. J.; Kuffler, S. W.; Dennis, M. J. Differential chemosensitivity of synaptic and extrasynaptic areas on the neuronal surface membrane in parasympathetic neurones of the frog, tested by microapplication of acetylcholine. Proc. Royal Soc. B, 1971, 177, 541-553.
[56] Brenner, H. R.; Martin, A. R. Reduction in acetylcholine sensitivity of axotomized ciliary ganglion cells. J. Physiol. (London), 1976, 260, 159-175.

[57] Carr, C. E.; Fourtner, C. R. A pharmacological analysis of a known synapse between sensory and motor elements in the cockroach. Am. Zool., 1978, 18, 578 .

[58] Carr, C. E.; Fourtner, C. R. Pharmacological analysisof a monosynaptic reflex in the cockroach, Periplaneta americana. J. Exp. Biol., 1980, 86, 259-273.

[59] Lee, D.; O'Dowd, D. K. Fast excitatory synaptic transmission mediated by nicotinic acetylcholine receptors in Drosophila neurons. J. Neurosci., 1999, 19, 5311-5321.

[60] Mandl, P.; Kiss, J. P. Role of presynaptic nicotinic acetylcholine receptors in the regulation of gastrointestinal motility. Brain Res. Bull., 2007, 72, 194-200.

[61] Coggan, J. S.; Paysan, J.; Conroy, W. G.; Berg, D. K. Direct recording of nicotinic responses in presynaptic nerve terminals. $J$. Neurosci., 1997, 17, 5798-5806.

[62] Stanley, E. F.; Goping, G. Characterization of a calcium current in a vertebrate cholinergic presynaptic nerve terminal. J. Neurosci., 1991, 11, 985-993.

[63] Yawo, H.; Momiyama, A. Re-evaluation of calcium currents in pre- and postsynaptic neurones of the chick ciliary ganglion. $J$. Physiol., 1993, 460, 153-172.

[64] Blagburn, J. M.; Sattelle, D. B. Nicotinic acetylcholine receptors on a cholinergic nerve terminal in the cockroach, Periplaneta americana. J. Comp. Physiol. A, 1987, 161, 215-225.

[65] Le Corronc, H.; Lapied, B.; Hue, B. M2-like presynaptic receptors modulate acetylcholine release in the cockroach (Periplaneta americana) central nervous system. J. Insect Physiol., 1991, 37, 647-652.

[66] Leitch, B.; Pitman, R. M. Modulation of transmitter release from the terminals of the locust wing stretch receptor neuron by muscarinic antagonists. J. Neurobiol., 1995, 28, 455-464.

[67] Knipper, M.; Breer, H. Subtypes of muscarinic receptors in insect nervous system. Comp. Biochem. Physiol. C. Comp. Pharmacol., 1988, 90, 275-280.

[68] Hue, B.; Lapied, B.; Malecot, C. O. Do presynaptic muscarinic receptors regulate acetylcholine release in the central nervous system of the cockroach Periplaneta americanaI ? J. Exp. Biol., 1989, $142,447-451$.

[69] Le Corronc, H.; Hue, B. Pharmacological and electrophysiological characterization of a postsynaptic muscarinic receptor in the central nervous system of the cockroach. J. Exp. Biol., 1993, 181, 257-278.

[70] Le Corronc, H.; Hue, B. Electrophysiological evidence for the modulation of acetylcholine release by endogenous acetylcholine in the cockroach central nervous system. J. Exp. Biol., 1993, 175, 305-310.

[71] Le Corronc, H.; Hue, B. Pharmacological properties of presynaptic muscarinic receptors in the sixth abdominal ganglion of the cockroach, Periplaneta americana. Pest. Sci., 1991, 33, 205-211.

[72] Trimmer, B. A. Characterization of a muscarinic current that regulates excitability of an identified insect motoneuron. J. Neurophysiol., 1994, 72, 1862-1873.

[73] Luetje, C. W.; Patrick, J. Both alpha- and beta-subunits contribute to the agonist sensitivity of neuronal nicotinic acetylcholine receptors. J. Neurosci., 1991, 11, 837-845.

[74] Bertrand, D.; Bertrand, S.; Ballivet, M. Pharmacological properties of the homomeric alpha 7 receptor. Neurosci. Lett., 1992, 146, 87 90.

[75] Seguela, P.; Wadiche, J.; Dineley-Miller, K.; Dani, J. A.; Patrick, J. W. Molecular cloning, functional properties, and distribution of rat brain alpha 7: a nicotinic cation channel highly permeable to calcium. J. Neurosci., 1993, 13, 596-604.

[76] Nelson, M. E.; Kuryatov, A.; Choi, C. H.; Zhou, Y.; Lindstrom, J. Alternate stoichiometries of alpha4beta2 nicotinic acetylcholine receptors. Mol. Pharmacol., 2003, 63, 332-341.

[77] Khiroug, S. S.; Khiroug, L.; Yakel, J. L. Rat nicotinic acetylcholine receptor alpha2beta2 channels: comparison of functional properties with alpha4beta2 channels in Xenopus oocytes. Neuroscience, 2004, 124, 817-822.

[78] Nevin, S. T.; Clark, R. J.; Klimis, H.; Christie, M. J.; Craik, D. J.; Adams, D. J. Are alpha9alpha10 nicotinic acetylcholine receptors 
a pain target for alpha-conotoxins? Mol. Pharmacol., 2007, 72, 1406-1410.

[79] Marshall, J.; Buckingham, S. D.; Shingai, R.; Lunt, G. G.; Goosey, M. W.; Darlison, M. G.; Sattelle, D. B.; Barnard, E. A., Sequence and functional expression of a single alpha subunit of an insect nicotinic acetylcholine receptor. EMBO J., 1990, 9, 4391-4398.

[80] Amar, M.; Thomas, P.; Wonnacott, S.; Lunt, G. G. A nicotinic acetylcholine receptor subunit from insect brain forms a nondesensitising homo-oligomeric nicotinic acetylcholine receptor when expressed in Xenopus oocytes. Neurosci. Lett., 1995, 199, 107-110.

[81] Jones, A. K.; Marshall, J.; Blake, A. D.; Buckingham, S. D.; Darlison, M. G.; Sattelle, D. B. Sgbeta1, a novel locust (Schistocerca gregaria) non-alpha nicotinic acetylcholine receptor-like subunit with homology to the Drosophila melanogaster Dbeta1 subunit. Invert. Neurosci., 2005, 5, 147-155.

[82] Gerzanich, V.; Peng, X.; Wang, F.; Wells, G.; Anand, R.; Fletcher, S.; Lindstrom, J. Comparative pharmacology of epibatidine: a potent agonist for neuronal nicotinic acetylcholine receptors. Mol. Pharmacol., 1995, 48, 774-782.

[83] Chavez-Noriega, L. E.; Crona, J. H.; Washburn, M. S.; Urrutia, A.; Elliott, K. J.; Johnson, E. C. Pharmacological characterization of recombinant human neuronal nicotinic acetylcholine receptors $h$ alpha 2 beta 2 , h alpha 2 beta 4 , h alpha 3 beta 2 , h alpha 3 beta 4 , h alpha 4 beta 2, h alpha 4 beta 4 and h alpha 7 expressed in Xenopus oocytes. J. Pharmacol. Exp. Ther., 1997, 280, 346-356.

[84] Stauderman, K. A.; Mahaffy, L. S.; Akong, M.; Velicelebi, G.; Chavez-Noriega, L. E.; Crona, J. H.; Johnson, E. C.; Elliott, K. J.; Gillespie, A.; Reid, R. T.; Adams, P.; Harpold, M. M.; CoreyNaeve, J. Characterization of human recombinant neuronal nicotinic acetylcholine receptor subunit combinations alpha2beta4, alpha3beta4 and alpha4beta4 stably expressed in HEK293 cells. $J$. Pharmacol. Exp. Ther., 1998, 284, 777-789.

[85] Wang, F.; Nelson, M. E.; Kuryatov, A.; Olale, F.; Cooper, J.; Keyser, K.; Lindstrom, J. Chronic nicotine treatment up-regulates human alpha3 beta 2 but not alpha3 beta4 acetylcholine receptors stably transfected in human embryonic kidney cells. J. Biol. Chem., 1998, 273, 28721-28732.

[86] Chavez-Noriega, L. E.; Gillespie, A.; Stauderman, K. A.; Crona, J. H.; Claeps, B. O.; Elliott, K. J.; Reid, R. T.; Rao, T. S.; Velicelebi, G.; Harpold, M. M.; Johnson, E. C.; Corey-Naeve, J. Characterization of the recombinant human neuronal nicotinic acetylcholine receptors alpha3beta2 and alpha4beta2 stably expressed in HEK293 cells. Neuropharmacology, 2000, 39, 2543-2560.

[87] Chamaon, K.; Schulz, R.; Smalla, K. H.; Seidel, B.; Gundelfinger, E. D.Neuronal nicotinic acetylcholine receptors of Drosophila melanogaster: the alpha-subunit dalpha3 and the beta-type subunit ARD co-assemble within the same receptor complex. FEBS Lett., 2000, 482, 189-192.

[88] Chamaon, K.; Smalla, K. H.; Thomas, U.; Gundelfinger, E. D. Nicotinic acetylcholine receptors of Drosophila: three subunits encoded by genomically linked genes can co-assemble into the same receptor complex. J. Neurochem., 2002, 80, 149-157.

[89] Goodman, C. S.; O'Shea, M.; McCaman, R.; Spitzer, N. C. Embryonic development of identified neurons: temporal pattern of morphological and biochemical differentiation. Science, 1979, 204, 1219-1222.

[90] Goodman, C. S.; Spitzer, N. C. Embryonic development of identified neurones: differenciation from neuroblast to neurone. Nature, 1979, 280, 208-214.

[91] Lane, N. J.; Swales, L. S.; David, J. A.; Sattelle, D. B. Differential accessibility to two insect neurones does not account for differences in sensitivity to alpha-bungarotoxin. Tissue Cell, 1982, 14, 489-500.

[92] Courjaret, R.; Lapied, B. Complex intracellular messenger pathways regulate one type of neuronal alpha-bungarotoxin-resistant nicotinic acetylcholine receptors expressed in insect neurosecretory cells (dorsal unpaired median neurons). Mol. Pharmacol., 2001, 60, 80-91.

[93] Courjaret, R.; Grolleau, F.; Lapied, B. Two distinct calciumsensitive and -insensitive PKC up- and down-regulate an alphabungarotoxin-resistant nAChR1 in insect neurosecretory cells (DUM neurons). Eur. J. Neurosci., 2003, 17, 2023-2034.

[94] Thany, S. H.; Courjaret, R.; Lapied, B. Effect of calcium on nicotine-induced current expressed by an atypical alpha-bungarotoxininsensitive nAChR2. Neurosci. Lett., 2008, 438, 317-321.
[95] Salgado, V. L.; Saar, R. Desensitizing and non-desensitizing subtypes of alpha-bungarotoxin-sensitive nicotinic acetylcholine receptors in cockroach neurons. J. Insect Physiol., 2004, 50, 867-879.

[96] Lambe, E. K.; Picciotto, M. R.; Aghajanian, G. K. Nicotine induces glutamate release from thalamocortical terminals in prefrontal cortex. Neuropsychopharmacology, 2003, 28, 216-225.

[97] Picciotto, M. R., Nicotine as a modulator of behavior: beyond the inverted U. Trends Pharmacol. Sci., 2003, 24, 493-499.

[98] Quik, M. Smoking, nicotine and Parkinson's disease. Trends Neurosci., 2004, 27, 561-568.

[99] Jensen, A. A.; Frolund, B.; Liljefors, T.; Krogsgaard-Larsen, P. Neuronal nicotinic acetylcholine receptors: structural revelations, target identifications, and therapeutic inspirations. J. Med. Chem., 2005, 48, 4705-4745.

[100] Gotti, C.; Zoli, M.; Clementi, F. Brain nicotinic acetylcholine receptors: native subtypes and their relevance. Trends Pharmacol. Sci., 2006, 27, 482-491.

[101] Threlfell, S.; Clements, M. A.; Khodai, T.; Pienaar, I. S.; Exley, R.; Wess, J.; Cragg, S. J. Striatal muscarinic receptors promote activity dependence of dopamine transmission via distinct receptor subtypes on cholinergic interneurons in ventral versus dorsal striatum. J. Neurosci., 2010, 30, 3398-3408.

[102] Klink, R.; de Kerchove d'Exaerde, A.; Zoli, M.; Changeux, J. P. Molecular and physiological diversity of nicotinic acetylcholine receptors in the midbrain dopaminergic nuclei. J. Neurosci., 2001, $21,1452-1463$

[103] Picciotto, M. R.; Addy, N. A.; Mineur, Y. S.; Brunzell, D. H. It is not "either/or": activation and desensitization of nicotinic acetylcholine receptors both contribute to behaviors related to nicotine addiction and mood. Prog. Neurobiol., 2008, 84, 329-342.

[104] Mansvelder, H. D.; McGehee, D. S. Long-term potentiation of excitatory inputs to brain reward areas by nicotine. Neuron, 2000, 27, 349-57

[105] Mansvelder, H. D.; Keath, J. R.; McGehee, D. S. Synaptic mechanisms underlie nicotine-induced excitability of brain reward areas. Neuron, 2002, 33, 905-919.

[106] Bicker, G. Histochemistry of classical neurotransmitters in antennal lobes and mushroom bodies of the honeybee. Microsc. Res. Tech., 1999, 45, 174-183.

[107] Oleskevich, S. Cholinergic synaptic transmission in insect mushroom bodies in vitro. J. Neurophysiol., 1999, 82, 1091-1096.

[108] Perez-Orive, J.; Mazor, O.; Turner, G. C.; Cassenaer, S.; Wilson, R. I.; Laurent, G. Oscillations and sparsening of odor representations in the mushroom body. Science, 2002, 297, 359-365.

[109] Yasuyama, K.; Meinertzhagen, I. A.; Schurmann, F. W. Synaptic organization of the mushroom body calyx in Drosophila melanogaster. J. Comp. Neurol., 2002, 445, 211-226.

[110] Grunewald, B. Morphology of feedback neurons in the mushroom body of the honeybee, Apis mellifera. J. Comp. Neurol., 1999, 404, 114-126.

[111] Ganeshina, O.; Menzel, R. GABA-immunoreactive neurons in the mushroom bodies of the honeybee: an electron microscopic study. J. Comp. Neurol., 2001, 437, 335-349.

[112] Szyszka, P.; Ditzen, M.; Galkin, A.; Galizia, C. G.; Menzel, R. Sparsening and temporal sharpening of olfactory representations in the honeybee mushroom bodies. J. Neurophysiol., 2005, 94, 33033313.

[113] Su, H.; O'Dowd, D. K. Fast synaptic currents in Drosophila mushroom body Kenyon cells are mediated by alpha-bungarotoxinsensitive nicotinic acetylcholine receptors and picrotoxin-sensitive GABA receptors. J. Neurosci., 2003, 23, 9246-9253.

[114] Gu, H.; O'Dowd, D. K. Cholinergic synaptic transmission in adult Drosophila Kenyon cells in situ. J. Neurosci., 2006, 26, 265-272.

[115] Yuan, N.; Lee, D. Suppression of excitatory cholinergic synaptic transmission by Drosophila dopamine D1-like receptors. Eur. J. Neurosci., 2007, 26, 2417-27.

[116] Cayre, M.; Buckingham, S. D.; Yagodin, S.; Sattelle, D. B. Cultured insect mushroom body neurons express functional receptors for acetylcholine, GABA, glutamate, octopamine, and dopamine. $J$. Neurophysiol., 1999, 81, 1-14.

[117] Goldberg, F.; Grunewald, B.; Rosenboom, H.; Menzel, R. Nicotinic acetylcholine currents of cultured Kkenyon cells from the mushroom bodies of the honey bee Aapis mellifera. J. Physiol., 1999, 514, 759-768. 
[118] Deglise, P.; Grunewald, B.; Gauthier, M. The insecticide imidacloprid is a partial agonist of the nicotinic receptor of honeybee Kenyon cells. Neurosci. Lett., 2002, 321, 13-16.

[119] Buckingham, S.; Lapied, B.; Corronc, H.; Sattelle, F. Imidacloprid actions on insect neuronal acetylcholine receptors. J. Exp. Biol., 1997, 200, 2685-2692.

[120] Thany, S. H. Agonist actions of clothianidin on synaptic and extrasynaptic nicotinic acetylcholine receptors expressed on cockroach sixth abdominal ganglion. Neurotoxicology, 2009, 30, 1045-1052.

[121] Tan, J.; Galligan, J. J.; Hollingworth, R. M. Agonist actions of neonicotinoids on nicotinic acetylcholine rececptors expressed by cockroach neurons. Neurotoxicology, 2007, 28, 829-842.

[122] Matsuda, K.; Buckingham, S. D.; Kleier, D.; Rauh, J. J.; Grauso, M.; Sattelle, D. B. Neonicotinoids: insecticides acting on insect nicotinic acetylcholine receptors. Trends Pharmacol. Sci., 2001, 22, 573-580.

[123] Matsuda, K.; Shimomura, M.; Ihara, M.; Akamatsu, M.; Sattelle, D. B. Neonicotinoids show selective and diverse actions on their nicotinic receptor targets: electrophysiology, molecular biology, and receptor modeling studies. Biosci. Biotechnol. Biochem., 2005, $69,1442-1452$.

[124] Tomizawa, M.; Casida, J. E. Neonicotinoid insecticide toxicology: mechanisms of selective action. Annu. Rev. Pharmacol. Toxicol., $\mathbf{2 0 0 5}, 45,247-268$

[125] Mohamed, F.; Gawarammana, I.; Robertson, T. A.; Roberts, M. S.; Palangasinghe, C.; Zawahir, S.; Jayamanne, S.; Kandasamy, J.; Eddleston, M.; Buckley, N. A.; Dawson, A. H.; Roberts, D. M. Acute human self-poisoning with imidacloprid compound: a neonicotinoid insecticide. PLoS One, 2009, 4, e5127.

[126] Phua, D. H.; Lin, C. C.; Wu, M. L.; Deng, J. F.; Yang, C. C. Neonicotinoid insecticides: an emerging cause of acute pesticide poisoning. Clin. Toxicol. (Phila), 2009, 47, 336-341.

[127] Butt, S. J.; Pitman, R. M. Modulation by 5-hydroxytryptamine of nicotinic acetylcholine responses recorded from an identified cockroach (Periplaneta americana) motoneuron. Eur. J. Neurosci., 2002, 15, 429-438.

[128] Butt, S. J.; Pitman, R. M. Indirect phosphorylation-dependent modulation of postsynaptic nicotinic acetylcholine responses by 5 hydroxytryptamine. Eur. J. Neurosci., 2005, 21, 1181-1188.

[129] Abel, R.; Rybak, J.; Menzel, R. Structure and response patterns of olfactory interneurons in the honeybee, Apis mellifera. J. Comp. Neurol., 2001, 437, 363-383.

[130] Strausfeld, N. J. Organization of the honey bee mushroom body: representation of the calyx within the vertical and gamma lobes. $J$. Comp. Neurol., 2002, 450, 4-33.

[131] Barbara, G. S.; Zube, C.; Rybak, J.; Gauthier, M.; Grunewald, B., Acetylcholine, GABA and glutamate induce ionic currents in cultured antennal lobe neurons of the honeybee, Apis mellifera. $J$. Comp. Physiol. A. Neuroethol. Sens. Neural. Behav. Physiol., 2005, 191, 823-836.

[132] Barbara, G. S.; Grunewald, B.; Paute, S.; Gauthier, M.; RaymondDelpech, V. Study of nicotinic acetylcholine receptors on cultured antennal lobe neurones from adult honeybee brains. Invert. Neurosci., 2008, $8,19-29$ 